\section{Darka Bilić}

Institut za povijest umjetnosti, Centar Cvito Fisković, Split

Izvorni znanstveni rad / Original scientific paper UDK / UDC: 725.13(497.5 Šibenik)

9. 9. 2013.

\section{Sudbina kneževe palače u Šibeniku u pozno doba Mletačke Republike}

Ključne riječi: Šibenik, kneževa palača, Frane Zavoreo, generalni providur, inženjer, Francesco Cicavo, Mletačka Republika Key words: Šibenik, The Rector's Palace, Frane Zavoreo, Provveditore generale, engineer, Francesco Cicavo, Republic of Venice

Tijekom druge polovine 18. stoljeća u Veneciju počinju sve češće pristizati molbe dalmatinskih gradskih knezova, kamerlenga $i$ kaštelana za obnovom njihovih rezidencija. Rezidencije državnih predstavnika u gradovima na obali pomalo su propadale, dok su javni dužnosnici, nakon bezuspješnih molbi za njihovu obnovu, stanovali u privatnim palačama za koje su plaćali najamninu. Novac za najamninu država je isplaćivala tek nakon što je državni inženjer sastavio izvještaj i troškovnik potrebnih radova za obnovu rezidencije. Često je tijekom zadnjih dvaju desetljeća 18. stoljeća od organa vlasti u Veneciji dolazila naredba da inženjer koji je sastavljao troškovnik obnove, istodobno sastavi procjenu vrijednosti građevine. S obzirom na razmjere oštećenja na rezidencijalnim građevinama, događalo se da su iznosi novca potrebnog za njihovu obnovu često nadmašivali tržišnu vrijednost samog objekta.

Takav je slučaj bio is kneževom palačom u Šibeniku. U tekstu će se pobliže analizirati dosada neobjavljenji brojni dokumenti iz Arhiva Mletačke Republike u Veneciji koji prate sudbinu kneževe palače kroz drugu polovinu 18. stojeća. Između ostalog donosi se izvještaj inženjera Francesca Cicava sastavljen 1784. godine nakon pregleda kneževe palače u Šibeniku te izvještaj inženjera Frane Zavorea iz 1788. godine koji sadrži projekt prenamjene palače te crteže palače koji su tom prilikom nastali.

Dalmacija, kao dio Mletačke Republike, iako na periferiji zapadne Europe, u 18. stoljeću ipak je neposredno osjetila posljedice dekadencije mletačkog društva i onemoćale države. Izravne posljedice financijski iscrpljene države i višegodišnjega neefikasnog administriranja provincije ogledale su se na građevinama u državnom vlasništtvu u cijeloj provinciji, od otoka Kvarnera do Neretve. ${ }^{1}$ Prema riječima Angela Mema IV. od 19. studenoga 1789. godine, netom nakon njegova povratka s dužnosti generalnog providura Dalmacije i Albanije, većina građevina u državnom vlasništvu bila je u jadnom stanju, njihova svrha se zloupotrebljavala u privatne interese ili su bile u potpunosti napuštene, a država nije imala pouzdane informacije o broju građevina u svom vlasništvu. ${ }^{2}$ Upravo je generalni providur Memo jedan od sudionika u prepisci između šibenskih knezova i mletačkih organa vlasti u Veneciji oko sudbine znatno oštećene kneževe palače u Šibeniku krajem 18. stoljeća.
Naime, šibenski palatium communis izgrađen je najvjerojatnije u drugoj polovini 13. stoljeća. Tijekom vremena palača se povremeno nadograđivala, a nakon dolaska mletačke vlasti u 15. stoljeću temeljito je preuređena. ${ }^{3}$ Primjer učinkovite administrativne procedure u slučaju obnove kneževe palače krajem 16. stoljeća u opreci je s nadasve kompliciranom i neučinkovitom administracijom s kraja 18. stoljeća čije su izravne žrtve bile upravo državne građevine. ${ }^{4}$ Naime, šibenski knez i kapetan Andrea Soranzo je 22. kolovoza 1599. u Šibeniku potpisao molbu upućenu mletačkom Senatu da mu se iz Venecije dostavi materijal (daske i crijep) za obnovu prozora i njihovih drvenih rebrenica na palači i novac u iznosu od pedeset dukata za isplatu majstora. Već 16. listopada iste godine, u Senatu je pročitana i odobrena molba kneza Soranza te je zapovjeđeno da mu službenici tijela Provveditori alle Fortezze pošalju navedenu količinu materijala te potreban novac za obnovu, a knez je imao 


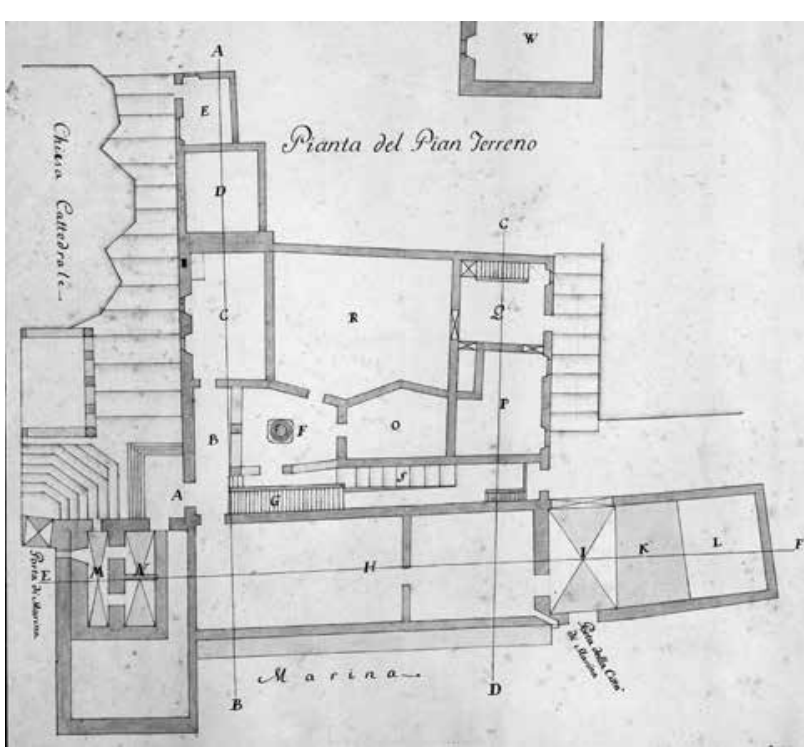

1. Tlocrt prizemlja kneževe palače u Šibeniku - postojeće stanje, F. Zavoreo 1788. (Legenda: A ulaz; B atrij; C stražarnica; D prostorija beneficija sv. Nikole; E trgovina stoljetnog beneficija; F dvorište s cisternom; $\mathrm{G}$ stubište iznad zatvorske prostorije; $\mathrm{H}$ skladište državnog alata; I nadsvedeni vestibul Morskih vrata; K stari zid; L vlasništvo gospodina Drage Bucchia; M pristup zatvoru u kuli; N zatvor u kuli; O zatvor u dvorištu; P podrum; $\mathrm{Q}$ štala; R dvorište; $\mathrm{S}$ rampa) / The plan of the ground floor of the Rector's Palace in Šibenik F. Zavoreo 1788 (A entrance; B atrium; C guard room; D room of St Nicholas' beneficium; $E$ The store of the beneficium; F court-yard with cistern; G staircase above the prison; $H$ Storage room of the State-owned tools; I vaulted vestibule of the Sea Gate; K the old wall; L property of Mr Drago Bucchia; M entrance to the prison in the tower; $N$ prison in the tower; $O$ courtyard prison; $P$ cellar; $Q$ stable; $R$ courtyard; $S$ ramp)

dužnost poslati službenicima ureda delle Fortezze račune kojima bi opravdao trošak.

No, problemi u kojima se nalazi kneževa palača u Šibeniku u 18. stoljeću znatno su teži, a administrativna procedura kojom se odobravala materijalna i financijska pomoć za obnovu bila je znatno kompliciranija kako to pokazuju sačuvani dokumenti iz zadnjih desetljeća mletačke vlasti istočnom obalom Jadrana. Prema dostupnim informacijama, posljednja obnova kneževe palače u Šibeniku tijekom 18. stoljeća odobrena je od mletačkih vlasti 3 . listopada 1771. godine. ${ }^{5}$ Naime, te je godine šibenski knez i kapetan Marco Contarini uputio generalnom providuru Dalmacije i Albanije molbu za obnovom koja je proslijeđena u Veneciju. Prema troškovniku u prilogu molbe, iz Venecije je poslan materijal i novac u iznosu nešto većem od 61 cekina. Ovom obnovom se najvjerojatnije nisu izvela dugoročna poboljšanja jer su generalnom providuru od rujna 1784 . godine opetovano iz Šibenika pristizale molbe predstavnika vrhovne vlasti za hitnom obnovom njihove rezidencije. Stoga je inženjer Francesco Cicavo dobio 16. rujna 1784. godine od generalnog providura Francesca Faliera zadatak da ode u Šibenik, ispita stanje u kojem se nalazi tamošnja kneževa palača, identificira najznačajnija oštećenja i sastavi

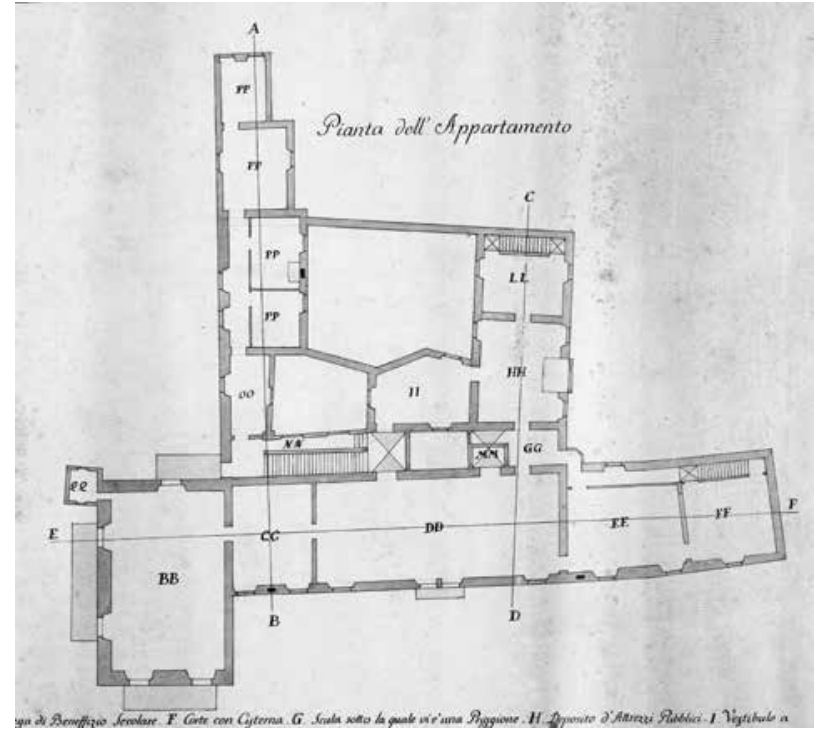

2. Tlocrt kneževa stana, postojeće stanje, F. Zavoreo 1788. (Legenda: BB dvorana u kuli; CC primaća soba; DD dvorana gradskog vijeća; EE dnevna soba; FF spavaća soba; GG prolaz prema kuhinji; HH kuhinja; II garderoba; LL passatizio; MM crkvica; NN hodnik koji vodi u knežev stan; OO portik kneževa stana; PP sobe kneževa stana; QQ sobica iznad Morskih vrata) / Plan of the Rector's apartment, F. Zavoreo 1788 (BB the hall in the tower; CC reception room; DD City Council Hall; EE living room; FF bedroom; GG kitchen passage; $H H$ the kitchen; II dressing room; $L L$ Passatizio; MM small church; NN corridor leading to the Rector's apartment; $O O$ portico of the Rector's apartment; PP rooms of the Rector's apartment; $Q Q$ small room above the Sea Door)

troškovnik neophodnih radova za privremenu obnovu prije nadolazeće zime. ${ }^{6}$

Obilaskom kneževe palače u Šibeniku u jesen iste godine inženjer Cicavo je uočio niz oštećenja koja su dovela u ozbiljnu opasnost javno dobro. Kako navodi u izvještaju od 7. listopada, ustanovio je da su krovne grede potpuno trule, što je dovelo do toga da se sobe pod krovom pri svakoj malenoj kišici napune vodom, a krovna konstrukcija na pojedinim mjestima čak prijeti urušavanjem. I svod iznad stubišta i primaće sobe je također bio truo. Drvena vrata soba, a i prozorski okviri te posebno drveni okviri balkona sale su bili trošni i morali su se popraviti. Također je bilo potrebno popraviti i cisternu u dvorištu palače koja je propuštala vodu, no ovo je bio jedan od manjih problema uzimajući u obzir opće stanje palače. Samo je za površne popravke neophodne prije nadolazeće zime inženjer Cicavo napravio troškovnik kojim je predvidio zamjenu trulih krovnih greda, zamjenu i učvršćenje crijepa na oštećenom krovu, izgradnju novog stropa iznad stubišta i primaće sobe te zamjenu svih starih drvenih vratnica kao i prozorskih okvira te popravak cisterne. Inženjer Cicavo je, da bi izvršio povjeren mu zadatak, sastavio i drugi troškovnik, za potpunu obnovu palače. Izradu drugoga, obuhvatnijeg troškovnika Cicavo je opravdao 


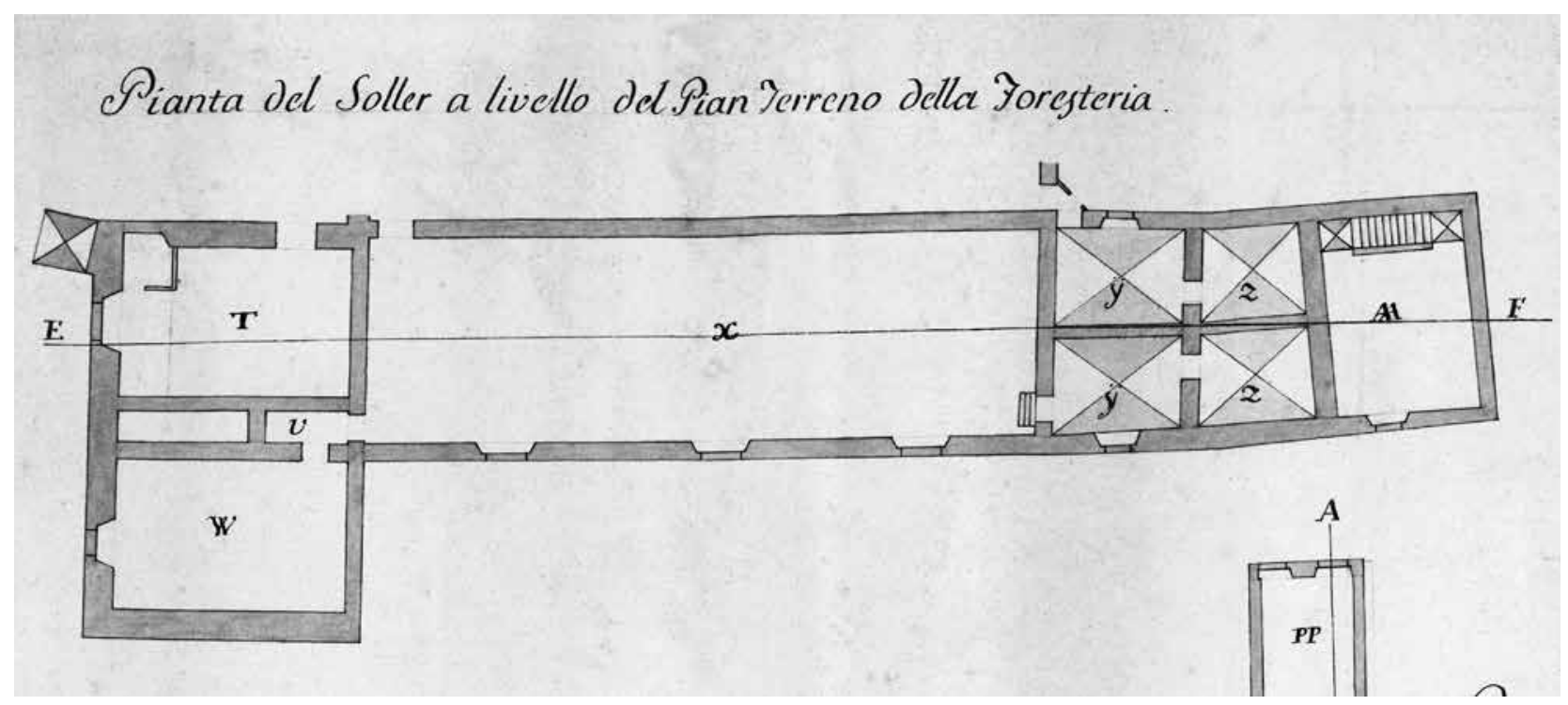

3. Tlocrt kata u prizemlju kneževa stana, postojeće stanje, F. Zavoreo 1788. (Legenda: T ured kaznenog suda; V pretprostor zatvora; W zatvor u kuli; X oružarnica; Y zatvor za žene; Z tamnica; AA soba za poslugu) / Plan of the Rector's apartment on the ground floor F. Zavoreo 1788 (T office of the penal court; $V$ anteroom of the prison; $W$ prison in the tower; $X$ armoury; $Y$ women's prison; $Z$ dungeon; $A A$ servants' room)

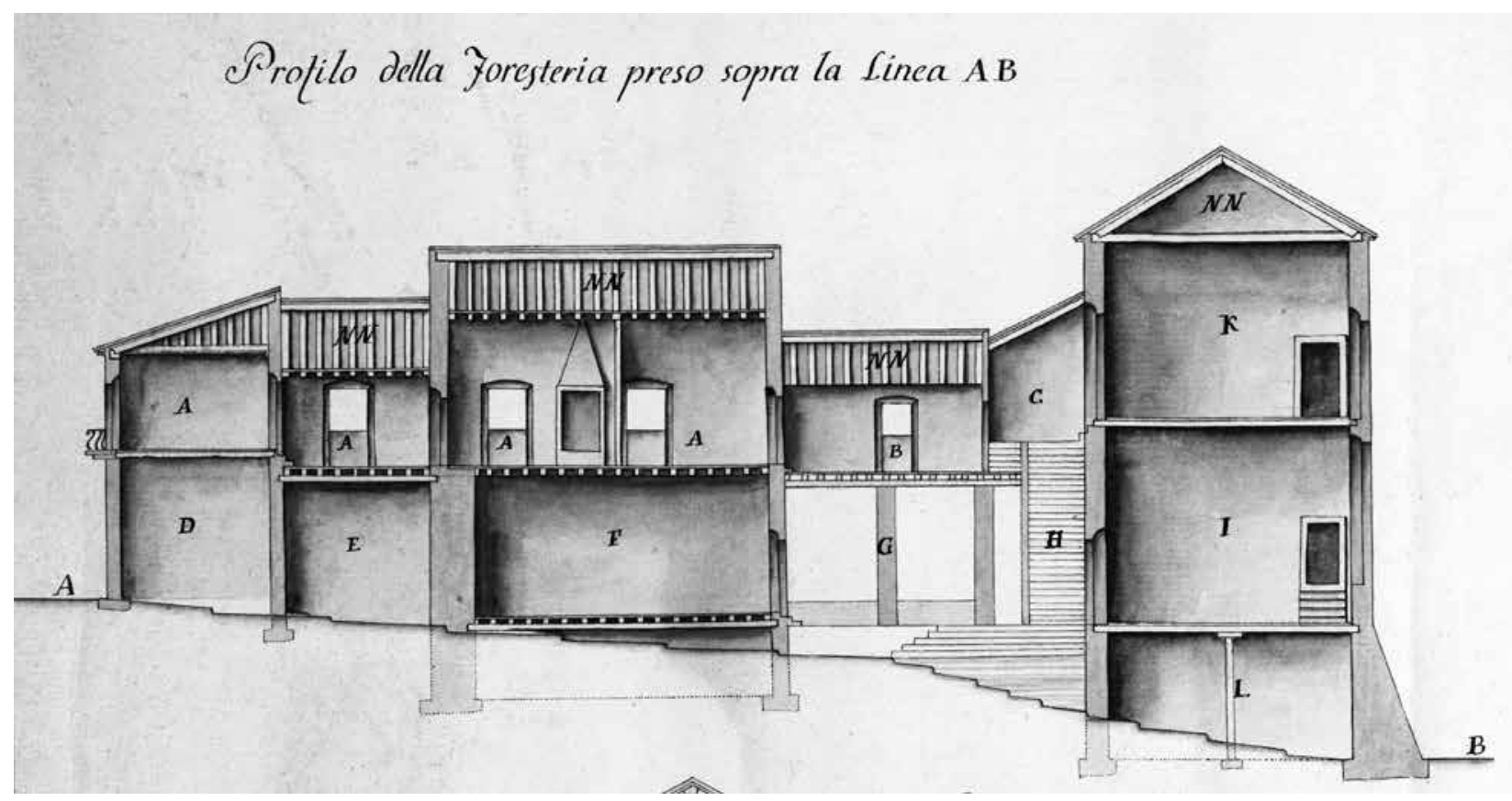

4. Presjek kneževa stana A - B, postojeće stanje, F. Zavoreo 1788. (Legenda: A sobe kneževa stana; B portik kneževa stana; C hodnik koji vodi u knežev stan; D trgovina stoljetnog beneficija; E prostorija beneficija sv. Nikole; F stražarnica; $\mathrm{G}$ atrij; $\mathrm{H}$ kameno stubište; I oružarnica; K dvorana gradskog vijeća; L skladište državnog alata; NN krovišta) / Section of the Rector's apartment, F. Zavoreo 1788 ( $A$ the rooms of the Rector's apartment; $B$ portico of the Rector's apartment; $C$ corridor leading to the Rector's apartment; $D$ store of the beneficium; E room of St Nicholas' beneficium; F the guard's room; G atrium; H stone staircase; I armoury; $K$ the City Council Hall; L storage room of the state-owned tools; NN the roof)

uvjerenjem da mali popravci nikada ne traju onoliko dugo koliko to zahtijeva javna blagajna te se trošak vremenom uvećava. U generalnoj obnovi, obuhvaćenoj drugim troškovnikom, namjeravao je zamijeniti sve krovove novima osim onoga u velikoj dvorani koji je bio nedavno obnovljen.
Troškovnik u kojem su popisani materijali koje je iz Venecije bilo potrebno poslati u Šibenik (drvena građa, crijep, opeka, olovo, čavli, željezo) pregledao je i potpisao arhitekt i vještak ureda delle Fortezze Zuanne Vettori. ${ }^{7}$ Osim materijala, inženjer Cicavo je naveo i sumu novca potrebnu 


\section{Profilo delli Luochi da Servizio preso sopra la Sinea CD}

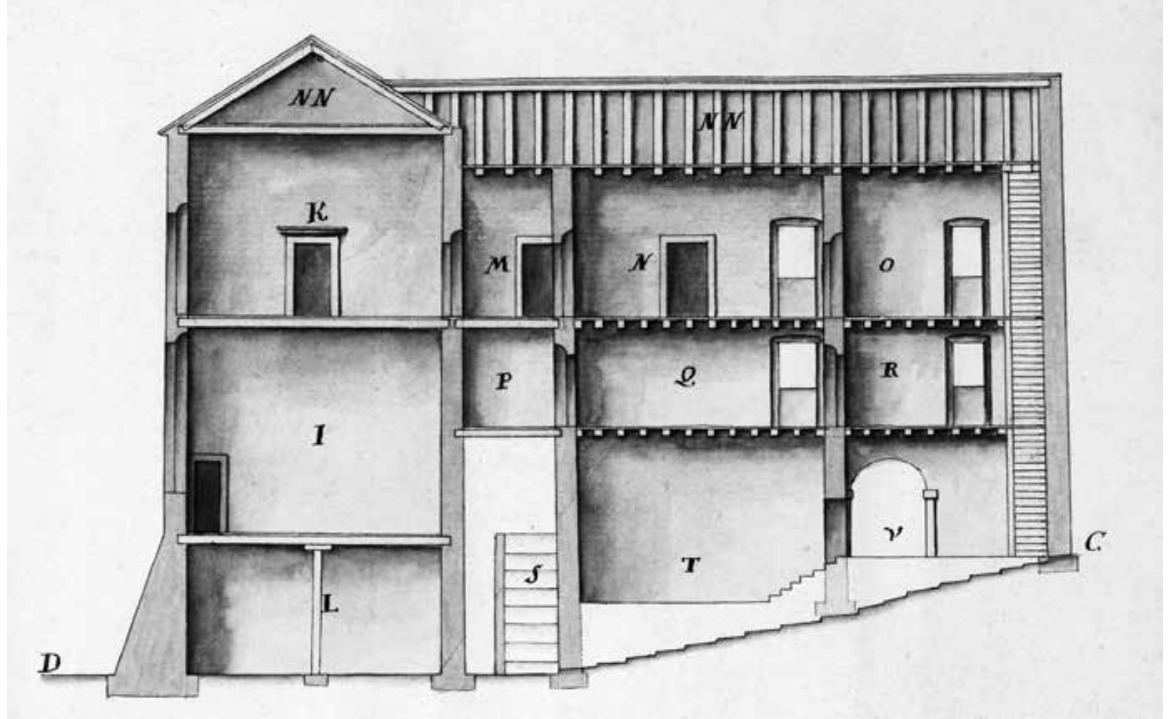

5. Presjek pomoćnih prostorija $\mathrm{C}-$ D, postojeće stanje, F. Zavoreo 1788 . (Legenda: I oružarnica; K dvorana gradskog vijeća; L skladište državnog alata; M hodnik koji vodi u kuhinju; N kuhinja; NN krovišta; O passatizio; P sobica; Q soba za poslugu; R passatizio; $\mathrm{S}$ rampa koja vodi u dvorište; $T$ podrum; $V$ štala) / Section of the auxiliary premises $C$ D, F. Zavoreo 1788 (I armoury; K City Council Hall; L storage-room of stateowned tools; $M$ corridor leading to the kitchen; $N$ the kitchen; $N N$ the roofs; $O$ passatizio; $P$ small room; $Q$ servants room; $R$ passatizio; $S$ the courtyard ramp; $T$ cellar; $V$ stable) za isplatu majstora koji bi izveli radove: zidara, drvodjelca, kovača i njihovih pomoćnika te manualnih radnika. Novac je bio potreban i za kupnju materijala u provinciji: vapna, pijeska, ali i nabavu kamena iz kamenoloma na Korčuli. ${ }^{8}$

Međutim, uz sav trud inženjera Cicava, opisani potrebni radovi nisu bili izvedeni nego je, prema riječima generalnog providura, izveden tek provizorni popravak najgorih oštećenja s veoma malim utroškom državnog novca. ${ }^{9}$ Dvije godine poslije palača je u još gorem stanju te se šibenski knez Antonio Donà žali generalnom providuru Falieru na njezino ruševno stanje, ističući moguću opasnost za ljudske živote i štetu kojom se narušava dostojanstvo države. Generalni providur Falier je iz Kotora, gdje se tada zatekao, 19. srpnja 1786. godine poslao troškovnike inženjera Cicava s molbom kneza Donà u Veneciju moleći vlasti da odobre potrebne radove. ${ }^{10}$ Projekt obnove palače pregledali su u Veneciji službenici ureda zaduženi za nadzor troška državnog novca, Deputati e Aggiunti alla provision del denaro publico ${ }^{11} \mathrm{i} 16$. rujna iste godine predložili Senatu da zbog dugoročne uštede državnih sredstava odobre novac i materijal potreban za cjelovitu obnovu rezidencije šibenskog kneza te da radove nadzire inženjer Cicavo ili neki drugi majstor prema njegovoj preporuci. ${ }^{12}$

Međutim, sasvim je izvjesno da i ovom prilikom mletački Senat nije odobrio potrebnu obnovu te da su budući šibenski knezovi tijekom dvije godine svoga mandata morali, često zajedno s obiteljima, stanovati u neadekvatnim, čak i za život opasnim državnim nekretninama. Šibenski knezovi nastavljaju s pritiskom na mletačke vlasti provincije. ${ }^{13} \mathrm{Za}$ vrijeme generalnog providura Angela Mema IV. prvi se put spominje mogućnost da se umjesto ulaganja u obnovu palače isplate novci za najam privatne kuće. ${ }^{14}$ Providur je marljivo prosljeđivao upućene mu molbe u Veneciju, a službenici ureda za nadzor troška državnog novca u Veneciji savjetovali su Senat, odlukom od 3. lipnja 1788., da odobri isplatu 120 dukata iz blagajne generalnog providura u Zadru za cijelo razdoblje službe za najam privatne kuće za rezidenciju kneza, što je Senat napokon i učinio 24. lipnja iste godine. ${ }^{15}$ Također, 5. kolovoza iste godine Senat je naredio generalnom providuru da nanovo dostavi detaljan izvještaj o stanju kneževe palače, procjenu njezine vrijednosti u slučaju prodaje te predloži adekvatniju namjenu za koju može poslužiti, sve to u svrhu donošenja daljnjih odluka u vezi palače. ${ }^{16}$

$\mathrm{Na}$ ovaj zadatak Memo je 5. rujna 1788. godine poslao inženjera Franu Zavorea. ${ }^{17}$ Providur je o inženjeru imao veoma visoko mišljenje ističući ga mletačkim vlastima među ostalim inženjerima navodeći da je sposoban, pouzdan, svestran i častan. ${ }^{18}$

U Šibeniku je inženjer Zavoreo proveo rujan i gotovo cijeli listopad te godine. Kako proizlazi iz njegova izvještaja, sastavljenog 26. listopada, došavši u Šibenik najprije je napravio crteže postojećeg stanja kneževe palače u tlocrtu, presjeku i profilu. Time je, prema vlastitim riječima, stvorio temelj iz kojeg je mogao precizno uvidjeti u kakvom se stanju nalazi palača, njezinu točnu vrijednost i moguću prenamjenu te uputiti na radove koji se moraju obaviti u skladu s budućim odlukama Senata. ${ }^{19} \mathrm{Na}$ jednoj je tabli iscrtao tlocrt prizemlja palače, tlocrt kneževa stana unutar palače i tlocrt kata u visini prizemlja foresterie, gostinjskih soba, označivši i imenujući na crtežu sve prostorije. Na drugoj je tabli prikazao tri različita presjeka palače također označujući funkciju svake prostorije. ${ }^{20}$

Zavoreo je zaključio da su perimetralni zidovi dijela građevine okrenutog prema moru, koji obuhvaćaju knežev stan, oružarnicu, zatvorske prostorije, urede i dvoranu komunalnog vijeća, u veoma dobrom stanju i dovoljno čvrsti da ne iziskuju popravak. Jednako široke i čvrste zidove ima i takozvana kula prema moru za razliku od zidova dvaju bočnih 


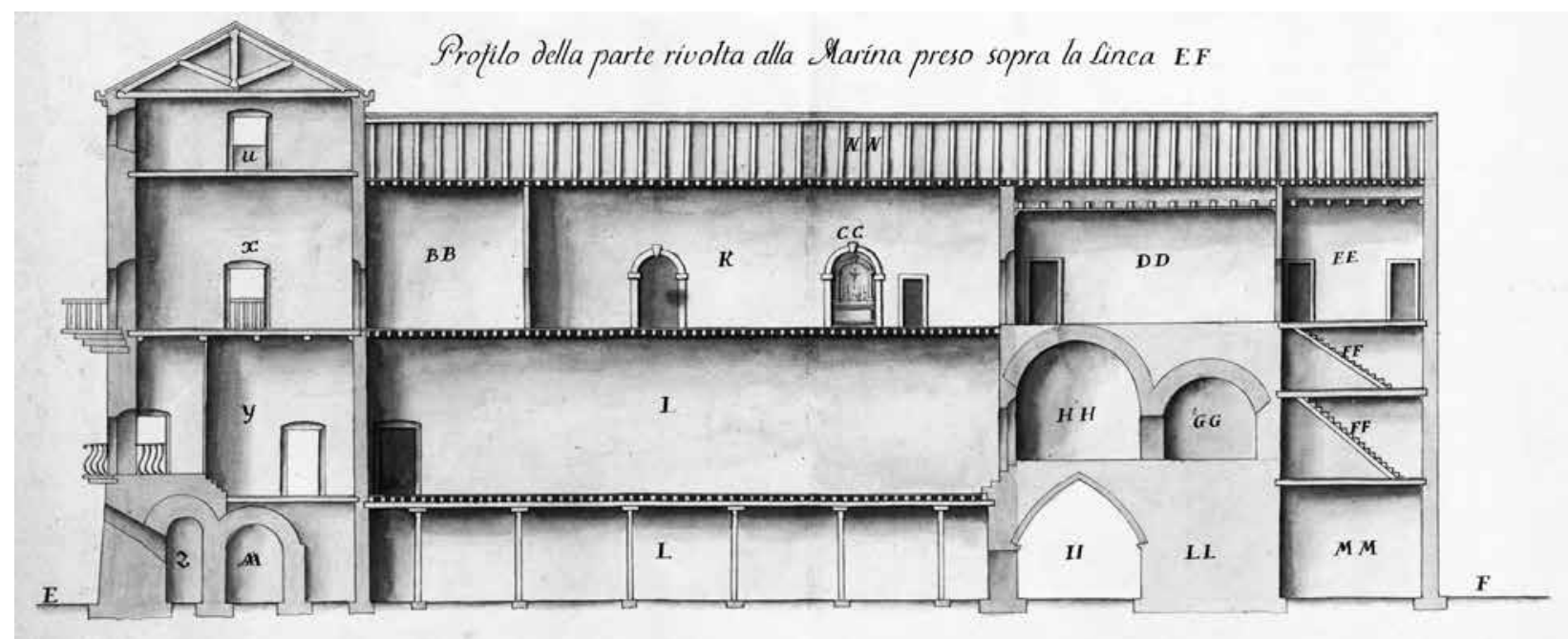

6. Presjek krila uz morsku obalu E - F, postojeće stanje, F. Zavoreo 1788. (Legenda: I oružarnica; K dvorana gradskog vijeća; L skladište državnog alata; U potkrovlje kule; X salon u kuli; Y ured kaznenog suda; Z hodnik zatvora u kuli; AA zatvor u kuli; BB primaća soba; CC kapelica; DD dnevna soba; EE spavaća soba; FF sobe za poslugu; GG tamnica; HH zatvor za žene; II vestibul gradskih morskih vrata; LL stari zid; MM vlasništvo gospodina Drage Bucchia; NN krovišta) / Section of the wing skirting the coast $E-F, F$. Zavoreo 1788 (I the armoury; $K$ the City Council Hall; L storage-room of state-owned tools; $U$ the tower; $X$ the drawing room in the tower; Y penal court office; $Z$ corridor of the tower prison; $A A$ tower prison; BB reception room; $C C$ small chapel; DD living room; EE bedroom; FF servants' rooms; GG dungeon; HH women's prison; II vestibule of the Sea Gate in the city ramparts; LL old wall; MM property of Mr Drago Bucchia; NN roofs)

krila koji nisu bili jednake kvalitete. Jedno od ova dva krila služilo je kao foresteria, a u drugom su se nalazile kuhinja, malo skladište, sobe posluge, štala i kantina. Zidovi krila u kojem je smještena foresteria bili su u posebno lošem stanju. Dijelovi zida su bili različite debljine, a poneki čak od sedre, materijala koji je veoma porozan te nije dovoljno čvrst da bi izdržao težinu nekoliko katova. Zidovi pak suprotnog krila morali su se, prema Zavoreovu mišljenju, dodatno učvrstiti gredama i povezati željeznim zategama jer nisu bili dovoljno široki s obzirom na visinu do koje su sezali. Inženjer Zavoreo nastavlja s opisivanjem ostalih oštećenja na drvenoj građi $\mathrm{u}$ pojedinim prostorijama te savjetuje zamjenu cjelokupne drvene građe na višim katovima zgrade jer je djelomično propala od starosti, a djelomično od utjecaja vlage. Posebno ističe veoma oštećen strop u oružarnici koji bi već bio propao da nije poduprt drvenom konstrukcijom. Također kritizira konstrukciju stropa dvorane za sastanke gradskog vijeća i prostorije za audijencije koja je, prema njegovu mišljenju, preteška te dodatno opterećuje već krhku strukturu. ${ }^{21}$ Strop u kuli pokraj dvorane velikog vijeća također je poduprt, a stropovi gostinjskih soba i uslužnih prostorija su u takvom stanju da osobe ne mogu stanovati u tim prostorijama. Sve krovne konstrukcije, osim one iznad navedene kule pored dvorane za sastanke velikog vijeća, moraju se u potpunosti rekonstruirati. ${ }^{22}$ Također, većina vratnica, prozora i prozorskih rebrenica i stubišta su raspadnute i moraju se zamijeniti. Ova oštećenja je inženjer Zavoreo pripisao izostanku povremenih radova na obnovi manjih oštećenja koja su u konačnici dovela do velikih šteta i troškova za njihovo saniranje.
Za sastavljanje troškovnika i izradu procjene palače Zavoreo se obratio za pomoć šibenskoj komuni koja ga je uputila na gradske majstore. Ovi majstori su dobro poznavali lokalno tržište nekretninama i mogli su dati ispravnu procjenu vrijednosti zemljišta na kojem je izgrađena palača, a i vrijednosti materijala koji se mogao dobiti razgradnjom palače na lokalnom tržištu. U procjeni vrijednosti su sudjelovali šibenski majstori zidari, klesari i drvodjelci Donat Pekić, Domenik Busti, kovač Juraj Ferrari, fenestrer (vjerojatno staklar) Ivan Krstitelj Cattarruzzi. Ukupna vrijednost palače prema ovoj procjeni iznosila je 3 127,10 cekina.

Zavoreo se u svom izvještaju prisjetio da je svojedobno maršal Johann Mattias von der Schulembourgh više puta u svojim izvještajima Senatu predlagao da se u Šibeniku izgrade skladišta za municiju i dvopek koja će dobro doći za opskrbu unutrašnjosti Dalmacije, nadasve tvrđave u Kninu. Iako je, prema Zavoreovu mišljenju, kneževa palača u Šibeniku dovoljno prostrana da udovolji ovoj namjeni, ipak navodi da postojeća struktura nedovoljno solidnih perimetralnih zidova ne može izdržati teret uskladištenog materijala, bilo da je riječ o oružju, alatu ili dvopeku. Stoga predlaže mletačkim vlastima prenamjenu postojeće palače u vojarnu za smještaj vojnika i časnika. Naime, vojnici koji su u to vrijeme boravili u Šibeniku, nisu bili smješteni u istoj gradskoj četvrti, nego su iznajmljivali stanove u kućama u vlasništvu gradskih bratovština. Prema mišljenju Zavorea, u državnom interesu je bilo da svi vojnici i njihovi časnici budu smješteni na jednom mjestu u istoj vojarni. ${ }^{23}$ Zavoreo nastavlja izvršavanje svoga zadataka izradom projekta prenamjene palače u vojarnu, 


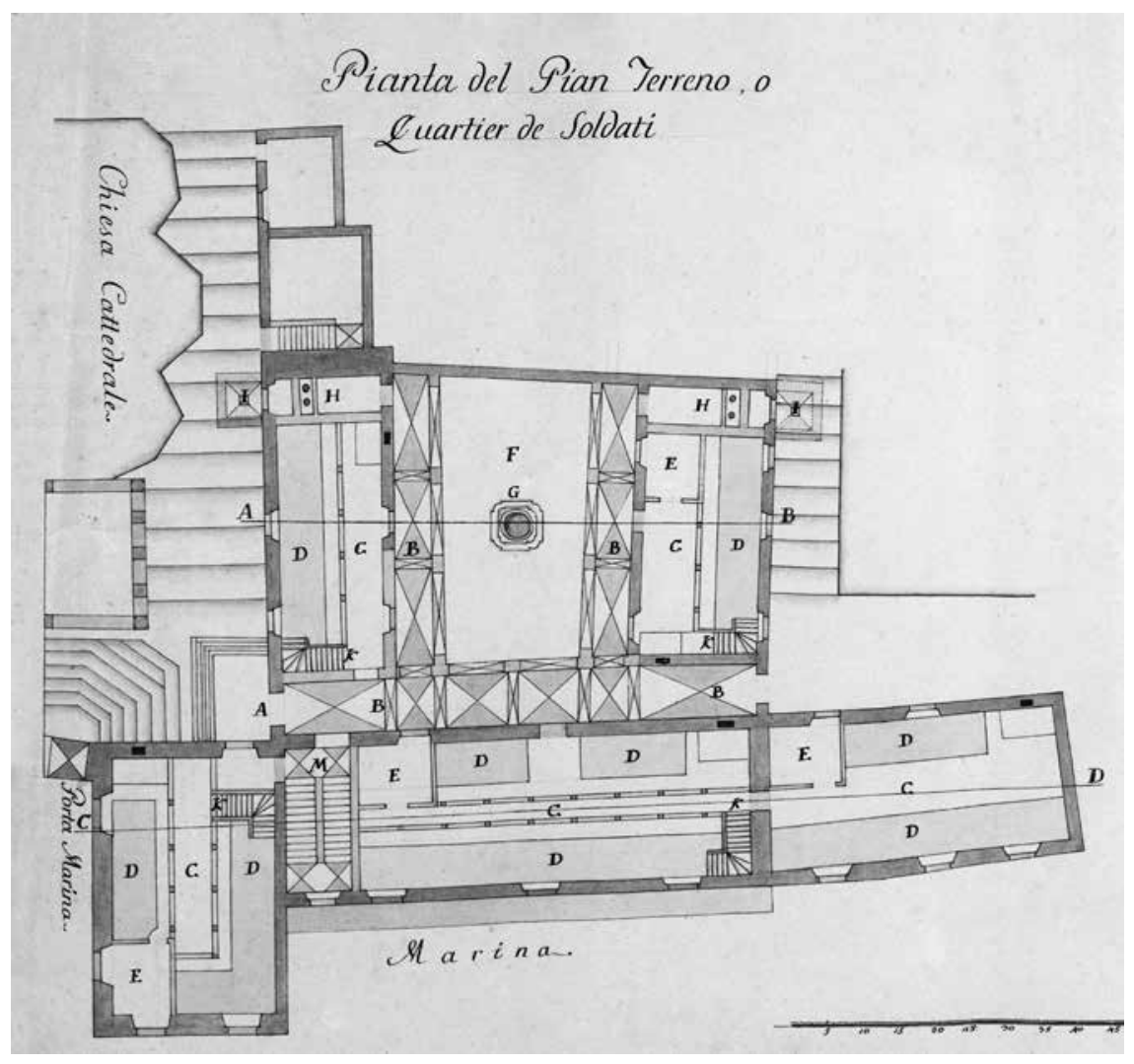

7. Tlocrt prizemlja vojarne, projekt prenamjene, F. Zavoreo 1788. / Plan of the barracks' ground floor, project for conversion, F. Zavoreo 1788

izgrade viši i čvršći zidovi foresterie i uslužnih prostorija te sruši postojeće stubište i unutrašnji dio zgrade u kojem se nalazi skladište da bi predviđeni stanovi dobili prozorske otvore. Na istom mjestu Zavoreo je zamislio hodnik ili natkrivenu galeriju iz koje bi se ulazilo u časničke stanove. Predloženim zahvatom na postojećem objektu inženjer Zavoreo je predvidio formiranje vojarne s kapacitetom za smještaj šest družina vojnika, nižih časnika i trinaest časnika. Svaki časnički stan sastojao bi se od tri različite prostorije, sobe, dnevne sobe i kuhinje.

Projekt prenamjene kneževe palače Zavoreo je predočio mletačkim vlastima tlocrtima i presjecima na predlažući da se postojeća oštećenja podnica i krova saniraju zamjenom novima, da se poveća katnost zgrade izgradnjom novih podnica u prostorijama koje su dovoljno visoke, nanovo dvije različite table. Na prvoj tabli je u tlocrtu prikazana vojarna za vojnike i niže časnike u prizemlju palače i stanovi za časnike na katu. Na drugoj tabli prikazan je projekt prenamjene palače s dva presjeka. Zahvati potrebni za realiziranje prenamjene palače na crtežima su istaknuti žutom bojom. Preinaka same palače u vojarnu za smještaj vojnika iznosila bi prema predviđenom troškovniku 1 687,12 cekina, ne uključujući cijenu materijala koji bi se trebao dopremiti iz Venecije. Premda je Zavoreo svjestan visine novčanih izdataka koju iziskuje predloženi projekt prenamjene palače, on ističe prednosti ovog zahvata. Jedna je od njih konačno rješenje problema ruševne palače njezinom sveobuhvatnom obnovom, umjesto dosadašnjih povremenih, parcijalnih i nekvalitetnih obnova koje su u

8. Tlocrt vojarne za časnike na prvom katu, projekt prenamjene, F. Zavoreo 1788. / Plan of of the officers' quarters on the first floor, project for conversion $F$. Zavoreo 1788 


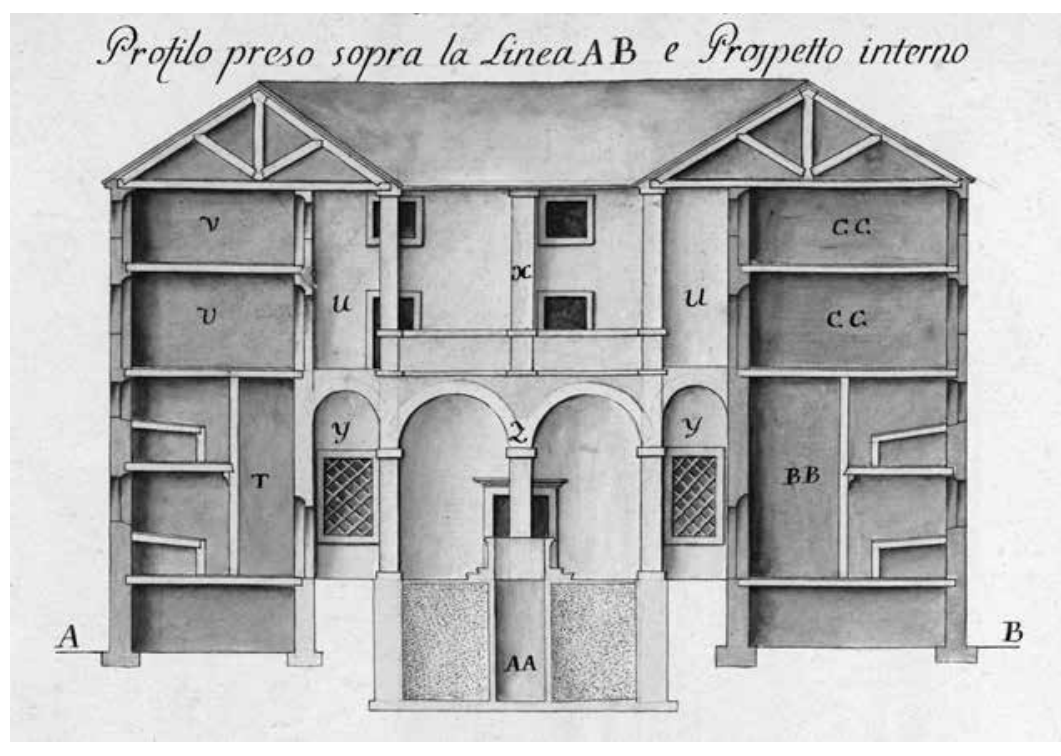

9. Presjek $\mathrm{A}-\mathrm{B}$, projekt prenamjene, $\mathrm{F}$. Zavoreo 1788. / Section $A-B$, project for conversion, F. Zavoreo 1788

konačnici državnu blagajnu koštale više nego kvalitetna i čvrsta obnova i pregradnja. Također ističe da se izvedbom ovog projekta trajno rješava problem financiranja smještaja vojnika u gradu. ${ }^{24}$ Osim prednosti izvedbe projekta, Zavoreo navodi i moguće negativne posljedice ovako složenog i zahtjevnog zahvata. Najveće probleme vidi u majstorima koji bi izvodili radove. Iz njegova izvještaja se doznaje da su majstori zaposleni na državnim gradilištima plaćeni manje nego na privatnim gradilištima. Također, Zavoreo ističe da tijekom ovako složenog zahvata može lako doći do niza različitih nereda na gradilištu koji se ne mogu predvidjeti. ${ }^{25}$ Osim problema oko izvedbe složenog zahvata, Zavoreo navodi da se u kneževoj palači trenutačno nalazi ured kaznenog suda i mnoge zatvorske prostorije te da bi u slučaju izvedbe projekta prenamjene za smještaj svih šest vojnih jedinica, koliko ih ukupno boravi u gradu, bilo potrebno izmjestiti navedene nog projekta prenamjene. Trošak obnove dijela palače koja je služila kao stan kneza iznosio bi prema Zavoreu 555,18 cekina.

Zavoreo se osvrnuo i na problem održavanja kneževe palače i ostalih građevina u državnom vlasništvu. Prema njemu, veliki dio oštećenja palače dolazi i od njezinih stanovnika. Kao rješenje ovog problema, Zavoreo mletačkim vlastima predlaže uspostavljanje dužnosti kvartir-mastra, službe koja, prema njemu, postoji u svim ostalim gradovima u provinciji. Osoba na dužnosti kvartir-mastra mogla je bolje nadgledati stanje i održavanje građevina te prokazati autore nastalih oštećenja.

$\mathrm{Da}$ bi predočio zamišljeni projekt, Zavoreo je izradio tlocrte i presjeke palače s označenim potrebnim preinakama na dvije različite table. Ovi crteži, kao i oni zatečenog stanja izrađeni istom prilikom, nose datum 26. listopada 1778. godine. Crteži nisu mogli nastati desetljeće prije izvještaja i troškovnika, nego je najvjerojatnije riječ o lapsus calami,

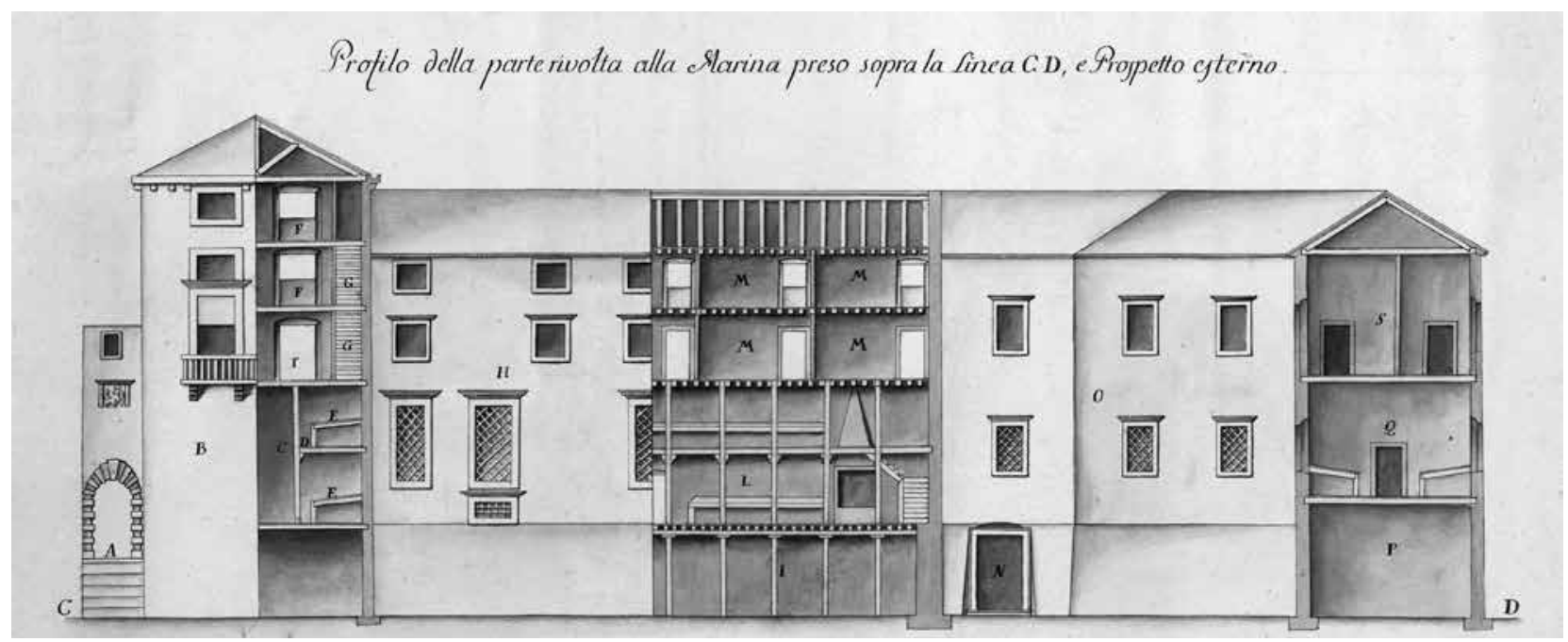

10. Presjek krila uz morsku obalu i djelomični pogled na pročelje, projekt prenamjene, F. Zavoreo 1788. / Section of the wing close to the sea coast and partial view of the front, project for conversion, F. Zavoreo 1788 
jer Zavoreo na istom listu spominje da su crteži izrađeni tijekom generalata providura Angela Mema. ${ }^{27}$

Generalni providur Memo je 2. ožujka 1789. godine u Veneciju sa svojim izvještajem proslijedio i crteže, izvještaj i troškovnike koje je sastavio inženjer Frane Zavoreo. Međutim, Senat nije pristao na realizaciju ni jednoga predloženog projekta te je odlučeno, s obzirom na to da se u sklopu palače nalaze oružarnica te dvorana za sastanke komunalnog vijeća, da se palača ponudi kao dar gradu Šibeniku. ${ }^{28}$ Iz ove darovnice bile su izuzete zatvorske prostorije, pisarnica i ostali državni uredi koje je, međutim, prema prijedlogu mletačkih vlasti, komuna trebala održavati o vlastitom trošku. Komuna je također trebala isplaćivati najam privatne rezidencije za gradskog kneza tijekom cijelog razdoblja njegova boravka u gradu. U međuvremenu je, nanovo, 23. rujna 1789. godine, gradskom knezu odobreno da uzme u najam privatnu kuću u kojoj će se smjestiti s obitelji, jer je gradska palača bila u tako lošem stanju da se u njoj nije moglo stanovati. ${ }^{29}$

12. srpnja 1792. godine generalni providur Angelo Diedo obavijestio je Senat da se u međuvremenu sastalo šibensko gradsko vijeće i s 15 glasova za i 4 glasa protiv prihvatilo prijedlog da komuna postane vlasnik palače. ${ }^{30}$ Također, vijeće je pristalo isplatiti 120 dukata gradskom knezu za najam privatne palače koju je međutim sam knez morao pronaći zbog, kako ističu, nemogućnosti pronalaska prikladno udobne i dostojanstvene zbog skromnog stanja privatnih kuća u gradu. Međutim, 1795. godine generalni providur Alvise Marin obavještava mletačke vlasti da nije uspio privoliti šibenske vijećnike da preuzmu obvezu obnove i održavanja državnih ureda unutar palače u visini od 60 dukata godišnje, nego su nastavili doznačavati novac za najam privatne rezidencije, dokje kneževa palača nastavila propadati dočekavši u takvom stanju i slom Mletačke Republike 1797. godine.

O izgledu palače nakon pada Mletačke Republike doznaje se iz putnog dnevnika habsburškog cara Franje I. iz 1818. godine. U njemu je car zapisao da tri krila palače zatvaraju dvorište s krunom bunara, da se u prizemlju krila prema moru nalaze dvije velike i prozračne zatvorske prostorije te dvorana koja je služila kao kazalište s dva reda drvenih loža. Car je ostao impresioniran veličinom i ljepotom brojnih prostorija na prvom katu istog krila od kojih su neke služile kao ured Okružnog povjerenika, a u drugom krilu su se nalazile prostorije mirovnog suca. Premda Franjo I. u dnevniku zapisuje namjeru da se u palači smjesti zapovjednike i upravu inženjerije, zaključuje da bi spomenutom pregradnjom ova lijepa zgrada izgubila na vrijednosti. ${ }^{31}$

\section{Prilog 1}

Coppia di lettera scritta all'Illustrissimo ed Ecceletissimo Signor Anzolo Memo 4.to Proveditor General in Dalmazia et Albania dall'Illustrissimo Conte, e Capitano di Sebenico in d.ta 4 Genaro 1788

Assunta questa Rappresentanza passai a formare il mio domicilio nel solito Publico Pretoreo Palaggio fissato per sua residenza ma ritrovai questa antica Publica Fabbrica in una totale desolazione e decandenza. Dalli Pub.ci Registri di questa Fiscal Camera ho raccolto che replicatamente dai N.N. H.H. miei Precessori fù esposto lo stato rovinoso del detto Palaggio all'Eccma Carica Genlzia in Prova a dalla quale per mezzo dell'Alfier Ingegner Cicavo fù fatta riconoscere in dettagliato fabbisogno ogni occorenza.

Confida la mia rassegnazione che assoggetata sia ogni cosa alla Sovrana Auttorità dell'Eccmo Senato, ma come ogni giorno più si fa maggiore precipizio cosi mi faccio lecito d'implorare da S. E. rappto sia nuovamente il bisogno alla Publica Sapienza per il relativo Compenso. Resta del tutto esposta la mia salute e quella della propria Famiglia per la rovinosa costituzione di detta Publica Fabbrica, ed esposto altresi alla rovina il mio allestimento con somma indecenza ed indecoro della mia Figura, e però astretto da tale necessità indispensabile devo non senza repugnianza dellanimo mio per il dispendio che derivar ne deve alla Pub.ca Cassa implorare sommenamente il conveniente riparo. Una sola privata Abitazione potrebbe servire a questa parte allalloggio di questa Publica Rappresentanza ma con l'affitto di Zecchini 50 all'anno, ma come reputa la rispetosa mia dipendenza molto più utile alli riguardi del Publico Interesse il ristauro del Publico Palaggio che sottostare al peso dell'annuo s??? esborso cosi ne faccio questo solo riverente cenno all'Eccelenza Vostra cui nella rispettosa aspetazione di qualche deliberazione nel proposito mi onoro in fine di baciarle umilmente le mani.

\section{Prilog 2}

Il Capitan Ingegnere Zavoreo ha per intiero esaurite le commissioni di questa Carica esecutive delle Lettere 5 Agosto di Vostra Eccelenza per risonoscere lo stato attuale del Publico Palazzo di Sebenico, rilevar il valore del Fondo, e suoi Materiali, ed indicar a quali usi potria surrogarsi quella Publica Fabrica. Risulteranno a Vostra Eccelenza le più precise categoriche dilucidazioni dal confronto analitico degli Estimi, de' Fogli, e del Disegno che rassegno alle osseguiati loro riflessi.

Qualunque siano per essere le sovrane successive deliberazioni su quel Publico Fondo, o di prescriverne la vendita, o di convertirlo ad altro publico uso; non è preteribile un adeguato riflesso sul destino dellarmamento, e della Sala del Consiglio dè Nobili di quella Città compresi in quella Publica Fabrica come dichiara lo stesso Ufficiale nella sua Relazione 
26 Ottobre decorso pervenutemi soltanto nel mese scaduto di Febbraro contrastandomene il ricapito dalla stravaganza notoria de' tempi, e distanza de' Luoghi.

Rimarcandosi pure nella medesima Relazione, che il deperimento dè Publici Stabili in quella Piazza nasca per la mancanza di Quartier Maestro che invigili al loro mantenimento, e buon sistema, e che risponda dè disordini, che di tratto in tratto accadono, e per parte di chi, non lascierà il mio impegno di prestar l'opportune considerazioni su quest articolo, cocrentemente alle Sovrane Ducali 8 Marzo1787, giuntemi poco prima del mio distacco da questa per passare nella Superiore Provincia motivo per cui non ho potuto in tanta lontananza contribuire i miei Studj sopra di questo affare onde esaurirlo baccio a Votra Eccelenza divotamente le mani

Zara 2 Marzo 1789.

Anzelo Memo 4.to

\section{Prilog 3}

Coppia di Lettra scritta all'Illustrissimo et Eccelentissimo Signor Angelo Diedo Provveditor Generale in Dalmazia et Albania dal Nobile Venerato Conte Capitano di Sebenico in data li 12 Luglio 1792

... e sembra che il dono medesimo sia stato assunto con la principal mira che non giunga a pervenir il stabile in poter de privati o a convertirsi in altro uso molto piu' che al momento della volontaria dedizione, resto' cesso il Palazzo stesso dalla Communita', come sta dichiarito, all'oggetto che servisse di decorosa e comoda residenza ai Pubblici Rappresentanti. Riffletono nella parte sudetta, che riportando il dono il suo effetto, riuscirebbe difficilissimo nell'angustia del Paese rinvenir privato alloggio capace, che combini i riguardi esenziali, che sodamente rimarcano, ed in fatti non esiste qui Casa opportuna, e se pur potesse ritrovarsi, non sarebbe sufficiente la restrinzion dellaffitto nella limitata summa di Ducati 120 valuta corrente per ogni Reggimento, qual Palazzo riddotto con qualche ristauro, come presentemente esiste, serve gia' all'uso dell'alloggio, ne abbisognarebbero spese di rimarco rimetterlo in sufficiente stato. Insuperabile il rifferito obbietto, quando anche fosse conciliabile il rinvenimento della Casa importarebbe in aggiunta di eccezione considerare che la scarssezza ordinaria del Presidio, non darebbe luoco poter divider, ed estender le militari custodie e per cio' diverebbero mal sicuri li Malfattori nelle Priggioni.

... Trovato al mio accesso a questa Rappresentanza esso pubblico Palazzo in urgenza imediata di cose indispensabili, ho dovuto per dura necessita', e per decenza, onde non lasciarmi esposto con le persone di famiglia all'intemperie, ed al pericolo, riparar l'alloggio, massime nella stagione autunale, e dell'inverno, che savvicinavano, facendo eseguir a proprie spese le fatture, e ristauro, dichiarite nellannesse tre Polizze de Capi Mistri Marangon, Fenestrer e Fabro le quali per glesborsi fatti nel rispettivo saldo, ascendono in tutto alla summa di $L$ 3350 di Dalmazia.

In tal occasione, e prima di far intraprender $i$ verificati lavori, avendo penetrato esser stata decrettata la massima di non render addmissibile, e che fu' anzi proibito ogni ristauro di Palazzo publico, riscontrai del pari da publici Documenti, che li due ultimi Reggimenti, cioe' delli NN VV Camillo Benzon, e Zanmaria Bembo ottennero col titolo d'affitto dalla Publica Cassa Ducati 120 valuta corente per caduno, che furono convertiti nella riparazione, che tratto tratto abbisogna, come lo e' di tutti glalloggi, e specialmente nelle Case, e Palazzi errette, e fabricate da secoli. Implorai percio' il compenso di equal summa, di cui l'esempio neglaccennati due recenti casi mi abbilitava collo stesso titolo d'affitto, che non corrisponde, ne saria l'intiero della spesa incontrata. L'equita' pubblica trovera' giusto, che sottostar non debba al peso dell'accannato esborso, originato dalla dichiarita necessita', e pero' suplico l'Eccelena Vostra col motivo di trasmetter la parte di questo cons.o scortare con la mia presente esposiz.ne le Polizze, che rassegno, affinche' casa in rifflesso, che al Pub.co conviene le riparazioni stesse, e che sarebbe singolar il caso, che rimanesse a mio carico l'incontrato aggravio monoro baciarle umilm. te le mani.

\section{BILJEŠKE}

1 Archivio di Stato di Venezia (dalje: ASVe), Colleggio, Relazioni, 70, Izvještaj bivšega generalnog providura Angela Mema IV. nakon povratka s dužnosti, 19. studenoga 1789.; DARKA BILIĆ, Generalni inventar $d r$ žavnih građevina u Dalmaciji iz 1789. godine, Radovi Instituta za povijest umjetnosti, 31 (2007.), 183, 187.

2 ASVe, Colleggio, Relazioni, 70, Izvještaj Angela Mema IV. nakon povratka s dužnosti, 19. studenoga 1789.: ... io non posso lasciar di richiamare alla Pubblica Conoscienza con vero sconforto dell' anima il misero stato delle Piazze, e Fortezze di Vostra Serenità nella Provincia della Dalmazia. Molte ve ne sono tra Forti, Torri, e Palache dalla prima isola del Quarner fino all estremità di Narenta, riguardanti lo Stato Austriaco, o l'Ottomano, e tutte desolate, ed inutili conservandone appena la loro figura, se al più si eccepiscano, qualunque siano le Fortificazioni di Zara.

3 O kneževoj palači u Šibeniku pisali su: GRGA NOVAK, Šibenik u razdoblju mletačke vladavine 1412.-1797. godine, Šibenik: spomen zbornik o 900. obljetnici, (ur.) Slavo Grubišić, Muzej grada Šibenika, Šibenik, 1976., 134-273; TONČIKA CUKROV, Kneževa palača u Šibeniku, diplomski rad, Filozofski fakultet, Zagreb, 1993.; JOSIP KOLANOVIĆ, Šibenik u kasnome srednjem vijeku, Školska knjiga, Zagreb, 1995.; DANKO ZELIĆ, Postanak i urbani razvoj Šibenika u srednjem vijeku, doktorska disertacija, Filozofski fakultet Sveučilišta, Zagreb, 1999.; JOSIP ĆUZELA, Šibenski fortifikacijski sustav, Gradska knjižnica »Juraj Šižgorić«, Šibenik, 2005.; KRASANKA MAJER JURIŠIĆ, Javne palače u Dalmaciji u vrijeme mletačke uprave, doktorska disertacija, Filozofski fakultet Sveučilišta, Zagreb, 2012.

4 ASVe, Senato Mar, 143: 1599: a: 16. di Ottobre in Pregadi, Essendo molto necessaria la riparatione del Palazzo di Sebenico, come dalle altre, che hora sono state lette questo Consiglio ha inteso.

L'Andarà parte, ch sia commesso alli Proveditori alle Fortezze, ch debbano mandare quanto prima al conte et capitano di Sebenico tavelle seicento, mezo miaro coppi; le quali robbe siano pagate delli danari della S.H., de' 
quali gli siano medesimamente mandati ducati cinquanta per far lo spradetto, dovendo esso Rettore nostro render conto all'Officio sopra le fortezze della spesa, che egli haverà fatta.

5 ASVe, Savio Cassier 41, Decreti Sommario 1730. - 1787., 28 marzo 1761 Ristauro Publico Palazzo Sebenico, 3 ottobre 1771 Ristauro Pub. Palazzo Sebenico.

6 ASVe, Savio Cassier 478, Sebenico: Copia di Lettera scritta all'Eccmo Signor Francesco Falier Provveditor General in Dalmazia et Albania dall'Alfier Francesco Cicavo in data 7 Ottobre 1784

Onorato di venerati comandi di Vostra Eccelenza con inchinato Foglio de di 16 settembre prossimo passato di dover esaminare li danni piu rimarcabili nel Palazzo Prettorio nella citta di Sebenico indicando quale dovesse essere il necessario Fabisogno per un provisionale ristauro indispensabile per la vegnente invernale stagione mi portai sopra luoco, e trovai in buona parte marciti li biscantieri de colmi, se sopratutto le sorrispondenti banchette tanto che in qualche luogo minacciano di cadere, e cio fa d'ogni piccola pioggia allaghi al di dentro per ogni dove le stanze con non poco Pubblico pregiudizio. E affatto marcito pure il soffitto sopra la Scala, e Camera d'udienza, e sono in gran disordine diversi scuri di porta, e Balcon, e specialmente qualli delle porte de Pergoli nella salla, e per fine la Cisterna nella corte del Palazzo stesso abisogna di qualche piccolo restauro, non essendo ben stagna, ma questo di poco momento per quanto mi fù possibile d'osservare. Per accorrere adunque al voluto provisionale ristauro estesi il Fabisogno segnato numero 1, che umilio all'Eccelenza Vostra, e questo servirà per rimettere di nuovo li più offesi Biscantieri, e Banchette ripassare tutti li copi de colmi rimettendo li mancanti far di nuovo il sopraacenato soffitto, essendo ciò indispensabile, ed accomodar tutti li Scuri da Porta, $e$ Balcon facendo da nuovo quelli, che abisognassero con anche il piccolo, ma necessario ristauro della Cisterna medesima. Credo pure di mio dovere il rassegnare all'Eccelenza Vostra un altro Fabisogno segnato numero 2 per il generale ristauro del palazzo istesso giacchè li provisionali, non hanno mai tanta durata quanto richiede la Publica Economia, e questa servirebe per far di nuovo tutti li colmi rovinosi eccetuato quello della Sala grande, che fù da poco tempo ristaurato oltre le altre già indicate fatture. Esaurito con ciò il venerato comando di Vostra Eccelenza passo le Tartta dall'auttorita' per lofficioo della Regenza

Zara 7 Ottobre 1784; Državni arhiv u Zadru (dalje: DAZd), Spisi generalnih providura, Francesco Falier, knjiga II.

7 ASVe, Savio Cassier 478, Sebenico.

8 ASVe, Savio Cassier 478, Sebenico.

9 DAZd, Spisi generalnih providura, Francesco Falier, knjiga II, 19. srpnja 1786.: Siccome però labitazione stessa abisognava in allora di qualche istantaneo riparo, nelle parti più rovinose, e cadenti, onde continuar potesse a soggiornarvi quel Pubblico Rappresentante cosi mi prestai soleccitamente nel volerlo effettuato in quelle misure di discretto dispendio, che nel complesso de Conti già opportunemente rassegnati sarà comparso a Pubblico osseguiato lume.

10 DAZd, Spisi generalnih providura, Francesco Falier, knjiga II, 19. srpnja 1786. : ... Scorsi però due anni dopo la verificazione degli indicati indispensabili ripari, non ha potuto a meno il Palazzo stesso notabilmente offesso nelle parti vitali di spiegare l'estrema sua necessità di un pronto accomodamento, come me lo significò il Nostro Honorevole Rappresentante attuale Antonio Donà coll'unita sua Lettera nella quale mettendo in vista il danno, il pericolo, e l'indecoro cui suggiace per la rovinosa situazione del proprio Pubblico Alloggio. Mi eccita efficaciamente di sottoporla alli Caritatevoli rifflessi di Vostra Serenità per glimmancabili Effetti delle Autorevoli sue providenze. Convinta perciò della realtà del bisogno, e persuaso che li riguardi del Pubblico interesse non ammettano ulterior remora alleffettuazione dell'occurente ristauro assoggetto all'Ecceletissimo Senato gli esemplari delli due sopra ennunziati Fabisogni - unitamente all'Informazione dell'Ufficiale Ingegnere ed alle Lettere del sudetto Pubblico Rappresentante per dipendere da quanto fosse per essere ingionto alla mia obedienza dalle Sovrane sue deliberazioni.

Cattaro, 19 Luglio 1786

11 ANDREA DA MOSTO, L'Archivio di Stato di Venezia - Indice generale, storico, descrittivo ed analitico, I, Rim, 1937., 121.
12 ASVe, Savio Cassier 478, Sebenico, 16. rujna 1786.: ... Ma considerando di quanta poca durata siano li Provisionali Ristauri non annaloghi alla Publica Ecconomia, Crediamo più opportuno l'applicarvi un Generale e solido accomodamento a tenore della trasmessa Perizia che stabilisce la Operazione da Praticarsi, e la spesa di Danaro occorente nella Summa di Z 7341 moneta di Dalmazia, che equivale a Zecchini 3364 moneta di Venezia, oltre li Materiali da spedirsi alla Dominante che pure sono dettagliati nella indicata Perizia.

13 ASVe, Savio Cassier 478, Sebenico, Coppia di lettera scritta all'Illmo ed Eccmo Signor Anzolo Memo 4.to Proveditor Generale in Dalmzia et Albania dall'Illustrissimo Conte, e Capitano di Sebenico in data 4 Genaro 1788, vidi Prilog 1.

14 ASVe, Savio Cassier 478, Sebenico, Coppia di lettera scritta all'Illustrissimo, ed Eccelentissimo Anzolo Memo 4.o Provveditor General in Dalmzia ed Albania dal Illustrissimo Conte Capitano di Sebenico in data 20 Febraro 1787 More Veneto. ... Implorai qualche provedimento, o sostituita con annuo affitto altra privata Abitazione per non riamnere esposto con la Persona, Famiglia, e mio allestimento a tutti quei disaggi e discapiti che porta massima inclemente staggione stringendo sempre più il bisogno mi faccio ardito nel rinovare all'Eccelenza Vostra le mie suppliche nel proposito confinando che lequità sua non vorrà più oltre lasciar esposto un suo concittadino all'incomodo che porta lo stato di calamità del detto Palazzo, e all'indecoro altresi che ne deriva alla Figura che rappresento.

15 ASVe, Savio Cassier 478, Sebenico: Copia di Lettera scritta dall'Illustrissimo, et Eccelentissimo Signor Anzolo Memo 4.to Provveditor General in Dalmazia, et Albania al Nostro Honorevole Conte Capitanio di Sebenico in data 12 Agosto $1788 .-$

Discesa la Sovrana autorità dell'Eccelentissimo Senato ad accordare con le inserte Ducali 24 Luglio decaduto a codesta Pubblica Rappresentanza la corrisponsione dell'Affitto per una privata abitazione in Summa di Ducati Cento, e venti Vostra Moneta per tutto lintierocorso del Reggimento di Vostra Signoria Illustrissima, nel porgerle il coerente rapporto per lume, sarannopoi dall'Officio mio Ecconomico eseguite le pubbliche disposizioni per lassantita contribuzione del danaro.

16 ASVe, Savio Cassier 478, Sebenico: 1788: 24: Luglio in Pregadi - Al Provveditore Generale in Dalmatia et Albania Ommissis: E delle presenti sia data Copia al Magistrato di Deputati et Aggiunti della Provvision del danaro in riscontro di quanto si delibera sull'Vostra lettera; e si incarica la nota sua vigilanza di rilevare esattamente lo stato in cui si attrova il Publico Palazzo di Sebenico, e sugerire la qualità dell'uso che se ne potesse fare; porgendosene il risultato per le conferenti Publiche terminationi.

17 ASVe, Savio Cassier 478, Sebenico, Prilog 2. Zavoreo je rođen u Veneciji od oca Nikole, mletačkog časnika, i majke Rose Burata u obitelji koja je podrijetlom iz Šibenika. O inženjeru Zavoreu vidi: KRUNO PRIJATELJ, Barok u Dalmaciji, ANĐELA HORVAT, RADMILA MATEJČIĆ, KRUNO PRIJATELJ, Barok u Hrvatskoj, Liber, Zagreb, 1981., 872; MARIJA STAGLIČIĆ, Klasicizam u Zadru, Institut za povijest umjetnosti, Zagreb, 1996., 69; NIKO DUBOKOVIĆ NADALINI, O gradnji cesta u Dalmaciji u doba Francuza, Odabrani radovi, (prir.) Neda Anzulović, Književni krug, Split, 2001., 430; MLADEN ANDREIS, Trogirsko plemstvo do kraja prve austrijske uprave u Dalmaciji (1805.), Muzej grada Trogira, Trogir, 2006., 342; DARKA BILIĆ, Inženjeri u službi Mletačke Republike, Književni krug, Split, 2013.

18 ASVe, Senato Provveditori di Terra e Mar 655, Zadar, 20. travnja 1789.: ... abile ed onorato Capitan Ingegner Zavoreo, esistente a questa Piazza alla Deputazion de' Confini (e che esperimentai molto esatto e capace in varie altre Comissioni, appogiategli in questa Provincia, anco durante la mia permanenza a Cattaro)...

19 ASVe, Savio Cassier 478, Sebenico

20 ASVe, Deputati e Aggiunti alla provision del denaro pubblico.

21 ASVe, Savio Cassier 478, Sebenico: ... Li Solleri poi in tutto o in parte hanno molti difetti. Quello dell'Armamento è affatto rovinoso, le Teste de travi sono marcite, e se non fosse stato puntellato da un caso all'altro a questora sarebe anco crollato. Quello della Sala di Consiglio de Nobili e della Camera d'Udienza, benche li Travi siano d'Arese, ha il massimo diffetto di poggiare sopra Fili di travo sostentati di Modioni di Pietra, quali in vece di legera la Fabrica fù anzi l'effetto di affiancarla maggiormente... 
22 ASVe, Savio Cassier 478, Sebenico: ... Fuori del colmo della Torre tutti li restanti devono essere intieramente rifabricati, e singolarmente quello che supore la parte rivolta alla Marina ha le Teste de Biscantieri assiano le unghie nella maggior parte marcite dal filtramento delle acque, e verisimilmente sarà lo stesso anche delle Banchette sopra le quali appoggiano, come lo è di alcune catene del Soffitto, benche di arese: diffetto accaduto collandar del tempo per aver trascurato i piccoli ristauri, che di tratto in tratto si rendono necessarij. Anche la maggior parte di Porte, Scuri da Balcon, Scale, e Finestre di vetro, sono marcite, e devono essere rimesse di nuovo...

23 ASVe, Savio Cassier 478, Sebenico: ... Non conviene alla grandezza del Sovrano che le sue Truppe non siano aquartierate, o che mendichino alloggi, o che se le dispongono nelle infelici Case delle Confraternità o Scuole Laiche, con molto disaggio riguardo a Soldati, e non peso poi esorbitante alla paga degl'Ufficiali per il loro particolar acquartieramento...

24 ASVe, Savio Cassier 478, Sebenico: ... Non è però che senza grave spesa, come si riscontra dall'unito Fabisogno, si possa rifabricare ad uso di Quartiere questo Pubblico Palazzo.

Fabricando massime per alloggiar Truppe, che è un composto di persone per lordinario di genio dissipatore, e di publica economia, che la Fabrica sia solida, e di lunga consistente durata, affinche colli continui ristauri, che di frequente occorreriano se si fabricasse poco solidamente, per studiare un mal inteso risparmio, non si aggravi maggiormente in seguito la publica Cassa con continue spese, le quali in poco tempo sormontariano a quel di più che si spendesse fabricando in modo solito, e robusto...

25 ASVe, Savio Cassier 478, Sebenico: ... Lunghi, e replicati Suoli di ottimo Legname, e Selciati, Colmi nuovi, Divisioni, e subdivisioni di muri, e di muneghini, quantità di Scale, di Porte, Finestre, Camini, Cisterna, Condotti di acqua, Latrine, Scaffe, e suoi condotti, archi, volti, salizzi, e paggiolati, abracciano una quantità di mano d'opera, che sebene siano pagate per conto Pubblico con qualche ecconomia in confronto del privato, pure sormontano a un dispendio non indiferente, e ad un generoso consumo de materiali, aggiungendo a tutto ciò l'impossibilità di prevedere tutti i disordini, che per avventura potriano incontrarsi nella Fabrica al caso di dar mano al lavoro.

26 ASVe, Savio Cassier 478, Sebenico: ... Supposte distrutte le attuali Prigioni, e l'Ufficio della Cancelleria, per convertire tutto il Palazzo in un Quartiere, converà che la publica Sapienza versi per provedere a questo essenzial oggetto del Governo, che non sarà di tanto facile riuscita in questa Piazza, ne si potrà suplire senza agravare con nuove spese la publica Cassa...

27 ASVe, Deputati e Aggiunti alla provision del denaro pubblico.

28 ASVe, Savio Cassier 478, ... Rilevando che nel recinto di quel Fabbricato trovasi l'Armamento, e la Sala del Consiglio della Citta' consideriamo miglior partito quello di offrire alla Citta' stessa in dono, ed a libera sua disposizione tutte le altre Fabbriche comprese in quel circondario, eccettuate pero' le Prigioni, la Cancelleria e li altri Publici Uffizij i quali dovrebbero essere da essa conservati, e mantenuti in perfetto stato, con lobbligo innoltre di corrispondere alli Nostri Honorevoli Rappresentanti la summa di Ducati 120 valuta corrente ogni Reggimento di e' quanto le viene ora corrisposto dalla Publica cassa per provvedersi d'una Casa privata...

29 U fondu ASVe, Savio Cassier 478 nalaze se troškovnici radova za koje iz sačuvanih dokumenata nije jasno jesu li izvedeni. Naime, 20. prosinca 1791. godine izrađen je troškovnik obnove drvenarije u palači, a troškom od 1678:10 lira. Jedan od troškovnika potpisao je majstor Antonio Marini, drvodjelac s plaćom od 1500 lira. 12. listopada iste godine majstor kovač Nicolo Giadron izradio je troškovnik radova na palači u iznosu od 1124:16 lira za trošak materijala, dok je njegova plaća za navedene radove iznosila 950 lira. I finestrer Antonio Angeli je u rujnu 1791. godine potpisao troškovnik u iznosu od 947 lira, dok mu je plaća bila 900 lira. Troškovnik radova supotpisao je knez i kapetan Šibenika i Skradina Zuanne Bragadin potvrđujući njihovu vjerodostojnost.

30 ASVe, Savio Cassier 478, vidi Prilog 3.

31 IVAN PEDERIN, Car Franjo I. o Šibeniku u svom putnom dnevniku iz 1818. godine, Radovi Zavoda Jugoslavenske akademije znanosti i umjetnosti u Zadru, 29-30 (1983.), 202. 
Summary

\section{Darka Bilić}

\section{Fate of the Rector's Palace in Šibenik during the Decline of the Venetian Republic}

During the second half of the 18th century Venice was bombarded by petitions in which the Venetian public administrators, camerlenghi and castellani of Dalmatian cities pleaded for the restoration of their palaces. The residences of the Venetian administrators in Dalmatia were in decline, but as their petitions often remained unanswered, the Rectors moved into private mansions for which they paid rent. The rent money was reimbursed by the State only after the state engineer had written a report and the cost estimate of the repairs. In the last two decades of the 18th century, Venice often sent requests to its engineers to make estimates of the value of these palaces along with the cost estimate for the repairs. Owing to the derelict condition of many of these buildings, the cost of necessary repairs was often higher than their actual value. This was the case with the Rector's Palace in Šibenik. This text offers an analysis of numerous as yet unpublished documents from the Archives of the Republic in Venice, which reveal the vicissitudes of the rectors' palace in Šibenik in the second half of the 18th century. One of them is the report of the engineer Francesco Cicavo made in 1784, after he visited the building, and the report of the engineer Frano Zavoreo made in 1788, which includes his project of the palace's conversion to another purpose along with the drawings of the building he made during his visit. 